\title{
Diagnosis and treatment process of comorbid bipolar disorder in a patient diagnosed with autism: Case report
}

\author{
Otizm tanılı bir hastaya bipolar bozukluk ek tanısı konulması ve tedavi \\ yönetimi süreci: Olgu Sunumu
}

Nermin Gündüz¹, Işık Karakaya², Hatice Turan³, Feyza Çelik

${ }^{1}$ Assist. Prof., Dumlupınar University Faculty of Medicine, Department of Psychiatry, Kütahya, Turkey https://orcid.org/0000-0002-01886232, https://orcid.org/0000-0003-2128-3014

2Prof. Dr., İstanbul Special Moodist Neurology and Psychiatry Hospital, Department of Child and Adolescent Mental Health, istanbul, Turkey https://orcid.org/0000-0001-8677-969X

3M.D., İstanbul Special Moodist Neurology and Psychiatry Hospital, Department of Psychiatry, İstanbul, Turkey

\section{SUMMARY}

Depression is one of the main psychiatric comorbidity reported in individuals with autism spectrum disorder (ASD). However, some cases of bipolar disorder accompanying ASD have been reported. In the past, there was a tendency to attribute all psychiatric problems in autistic children and adults to autism itself. Nowadays, there is not only an increase in the number of studies on other medical conditions especially neurological conditions in ASD but also there is an increasing effort in defining the comorbide psychiatric disorders. Comorbid psychiatric conditions can make disease management difficult in cases of autism. The precise and reliable diagnosis of psychiatric disorders accompanying children and adolescents with autism is of great importance. More specific treatment options are possible when problematic behaviors are accepted only as a manifestation of comorbid psychiatric disorder from isolated behavior. In this case report, we aimed to present the diagnosis and management of an adolescent autism diagnosed patient and comorbid bipolar disorder.

Key Words: Bipolar disorder, mania, autism, valproate, pervasive developmental disorder

\section{ÖZET}

Depresyon, otizm spektrum bozukluğu (OSB) tanılı hastalarda bildirilen başlıca psikiyatrik ek tanılardandır. Bununla birlikte son yıllarda OSB tanılı bireylerde eşlik eden bipolar bozukluk tanıları da bildirilmeye başlanmıştır. Geçmişte ne yazık ki otizm tanılı çocuk ya da erişkin hastalardaki ruhsal sorunların önemli bir kısmı otizmin kendisine bağlı davranış sorunlarına atfedilmekte idi. Günümüzde nörolojik ek tanılar başta olmak üzere OSB'na eşlik eden diğer tıbbi durumlar üzerine yapılan çalışmaların sayısındaki artışın yanısıra OSB'ye eşlik eden psikiyatrik bozuklukların tanımlanmasında da gideren artan bir çaba bulunmaktadır. OSB tanılı hastalardaki psikiyatrik ek tanılar hastalığın tedavi yönetimini güçleştirmektedir. Bu nedenle bu ek ruhsal tanıların erken tanınması ve tedavi planının oluşturulması önemlidir. Biz bu vaka bildiriminde, bipolar bozukluk ek tanılı ergen bir OSB vakasında tanı konulması ve tedavi sürecini anlatmayı amaçladık.

Anahtar Kelimeler: Bipolar bozukluk, mani, otizm, valproat, yaygın gelişimsel bozukluk 


\section{INTRODUCTION}

Autism spectrum disorder; Autism, Asperger's disorder, pervasive development disorder-not otherwise specified and Disintegrative disorder have been collected under the same title by excluding the Rett disorder in DSM-5 (1). In the past, there was a tendency to attribute all psychiatric problems in autistic children, adolescents and adults to autism itself (2). Possible reason may be that the autism spectrum disorder may involve a serious and comprehensive labeling of the psychiatric problems that may occur secondary, tertiary or later in the disease (3). Nowadays, there is not only an increase in the number of studies on other medical conditions especially neurological conditions in autistic individuals but also there is an increasing effort in defining the comorbide psychiatric disorders (4).

Depression is one of the main psychiatric comorbidity in individuals with autism spectrum disorder $(5,6)$. However, some cases of bipolar disorder accompanying autism spectrum disorder have been reported $(7,8)$. Literature emphasizes the comorbidity between autism spectrum disorder and mood disorders especially depression and bipolar disorder $(9,10)$. But depressive symptoms are sometimes recognized in high-functioning autistic individuals while hypomanic symptoms are often overlooked and undiagnosed. Also high-functioning autism itself is sometimes not recognized and not diagnosed in adolescents or young adults with other psychological complaints (11).

Of course, comorbid psychiatric conditions can make disease management difficult in autism. The precise and reliable diagnosis of psychiatric disorders accompanying children and adolescents with autism is of great importance. More specific treatment options are possible when problematic behaviors are accepted only as a manifestation of comorbid psychiatric disorder from isolated behavior (4). Thus, in this case report, we aimed to present the diagnosis and management procedure of manic episode in an adolescent patient diagnosed with autism. Written informed consent was obtained from the patient and his family who were followed up regularly in our clinic.

\section{CASE REPORT}

16 years old male adolescent patient who was diagnosed with autism when he was 4 years old admitted to our outpatient clinics with the complaints of sleep disturbances, irritability, increased motor activity, increased rate and amount in the speech and agressive behaviors.

\section{Psychiatric History}

He completed 8th grade of integration class. He is the only child of a family living as a core family. His parents had no psychiatric history.

He had neuromotor developmental retardation like sitting, walking and speaking. He was taken to a child psychiatry outpatient clinics with the complaints of lack of facial expressions and abnormalities in eye contact and body language, delay in speaking, stereotyped or repetitive motor movements like lining up toys or flipping objects and sleep disturbances when he was 4 years old. He was diagnosed with autism. He had different psychopharmacological treatment regimens like fluoxetine, methylphenidate and risperidone because of overreacting to changes, sleep distrubances and behavioral problems.

His overreacting to the changes like new shoes and clothes, television channels, bus-stops, school desk increased seasonally for the last 4 years. Because of the decreased need for the sleeep, he was sleeping late at night and waking up early. He had irritability and hostile attitudes and behaviours towards his parents. He had verbal and physical violence like damaging the equipments around him. He had selftalk, increased psychomotor activity, increased speed and amount of speech. He was also more lively, energetic and cheerful than normal. He had platonic love towards the people he saw on television. These symptoms began in the spring and lasted until the summer for the last 4 years. He had a platonic love towards one of his classmates last year. He had physical and verbal violence to other friends when they got close to his platonic love. Thus, his mother often had to go to the school because of his hostility in the classroom. As the patient's complaints increased seasonally 4 months 
ago, risperidone $0,5 \mathrm{mg}$ per day was given to him by his parents. His sleep returned to normal after risperidone. But, his hostile behaviour towards his family and classmates continued. Also he had persecution delusions -thinking that his classmates planned a game to seperate him from the girl he interested in and he had also erotomanic delusions -thinking that other girls in the class fell in love with himself. Because of the behavioral problems he had in the school like irritability, agression, swearing, dividing lessons with a lot of speech, damaging his friends, he was taken from the school. But his psychiatric complaints increased in the compulsory holiday in the house. He had psychomotor agitations because he could not sleep despite the risperidone $1 \mathrm{mg}$ per day. Also he had increased libido. He masturbated when he saw a woman wearing especially jeans. When he was brought to the school for the final examination, he attacked his friend during the examination because of his paranoid thoughts.

\section{Clinical follow-up and treatment}

Complete Blood Count, biochemistry, thyroid function tests were all normal. Magnetic resonance imaging (MRI), electroencephalogram (EEG) and pediatric neurological consultations were reported to be normal. Also there were no environmental changes that could explain or contribute to the patient's complaints. In the light of the psychiatric history taken from his family and himself and the mental state examination of the patient, he was diagnosed with High Functional Autism and Bipolar I disorder Manic episode psychotic feature according to DSM 5. Also we learnt that he didn't have any depressive episode. Following family psychoeducation about the disorder due to manic symptoms valproate $400 \mathrm{mg}$ per day as a mood stabilizer and risperidone $2 \mathrm{mg}$ per day for the psychotic symptoms were started. Manic symptoms were followed by Young Mania Rating Scale (YMRS). During the weekly follow up period, scores of YMRS were found to be 39-30-28-11 points respectively. We observed markedly improvement in manic symptoms, psychomotor agitation and psychotic symptoms after four weeks follow up. The follow-up of the patient continues with the remission. The blood Valproate level of the patient was measured as 47,94 .

\section{DISCUSSION}

Here we presented the diagnosis and management procedure of manic episode in a 16-year old adolescent patient diagnosed with autism in an adult psychiatry unit. Although depression is one of the main psychiatric comorbidity in autism spectrum disorder (6), the increase in relevant studies about the comorbidity of Bipolar Disorder and Autism Spectrum Disorders is noteworthy in the recent years $(8,11)$. In a comparative study conducted among 438 high-functioning autistic patients with a mean age of $12.7 \pm 3.2 ; 2.1 \%$ of these patients were found to have Bipolar Disorder (12). In another study conducted among 66 patients diagnosed with autism spectrum, 14 of these patients were diagnosed with mania as a comorbid psychiatric condition (10). Our patient was diagnosed with autism when he was 4 years old and during the last 4 years he had seasonal cycle manic and hypomanic episodes. Behavioral symptoms observed during the patient's manic or hypomanic episodes were attributed to autism itself by the family and risperidone was given to the patient. But the symptoms did not regress. Also he had erotomanic and persecution delusions and hostile behaviors towards the family and friends because of his delusions. He also had decreased need for sleep and increased libido, psychomotor mobility and speech. He was diagnosed with comorbide Bipolar I disorder Manic episode psychotic feature according to DSM 5.

In a study conducted among 35 patients with Asperger Syndrome, 13 patients $(37,1 \%)$ were reported to have a mood disorder according to DSM IV. Of these 13 patients, 8 had MDD, 4 had dysthymic disorder, and 1 had BPD (6). Wozniak et al. reported that $21.2 \%$ of 66 patients with autism (57 of them high-functioning autism) had mania as a mood disorder in their study (10). These findings emphasize that clinicians should pay attention to manic and hypomanic symptoms in adolescents and young adults with autism especially with high-functioning autism.

There are also biological similarities between these two disorders (e.g. decreased serum melatonin levels $(13,14)$ and impaired sleep and circadian rhythms $(15,16)$. Thus, the clinicians must carefully 
question the sleep disturbances in their patients with autism in order to clarify the accompanying mood disorders especially mania or hypomania. Our patient had decreased need for sleep which was evident for seasonally.

Although the accompanying mood disorders are well defined in autism, there is very little information about the treatment of comorbid bipolar disorder in adolescents with autism spectrum disorder (17-19). Lainhart et al. found that classical antipsychotics such as haloperidol, chlorpromazine, thioridazine, and mood stabilizers such as lithium and carbamazepine are less effective in treating mania in children with autism (17). Contrary to this, in the new double blind placebo controlled studies, it has been proven that second generation antipsychotic risperidone is well tolerated and effective in managing irritability, destructive, aggressive, and selfharmful behavior in young people with autism $(18,19)$. Also, in a case report reported by Frazier et al. comorbid bipolar disorder in a patient diagnosed with Asperger's Syndrome, patient's behavioral symptoms were reported to improve after treatment with lithium, risperidone and clonazepam (7). Because our patient had severe irritability, hositility and destructive behaviours like damaging the equipments and his friends and psychotic symptoms like delusions of percetuion and erotomanic delusions, risperidone was started and sodium valproate was added as a mood stabilizer agent in the treatment of the patient.

In our daily clinical practice, depressive symptoms in autism are sometimes unrecognized, while hypomanic and manic symptoms are often unrecognized or overlooked (20). In this case report, we wanted to emphasize that clinicians should carefully question the symptoms of mood diorders that may be attributed to autism in patients with autism.

Correspendence Adress: Assist. Prof. Nermin Gündüz, Department of Psychiatry, Dumlupınar University, Kütahya, Turkeyngunduz2798@hotmail.com 


\section{REFERENCES}

1. American Psychiatric Association, Diagnostic and Statistical Manual of Mental Disorders, Fifth Edition (DSM-5), Arlington VA, 2013

2. Lainhart JE. Psychiatric problems in individuals with autism, their parents and siblings. Int Rev Psychiatry 1999;11:278-298.

3. Bolte S, Bosch G. The long-term outcome in two females with autism spectrum disorder. Psychopathology, 2005;38:151-154.

4. Leyfer OT, Folstein SE, Bacalman S, Davis NO, Dinh E, Morgan J, Tager-Flusberg H, Lainhart JE. Comorbid psychiatric disorders in children with autism: interview development and rates of disorders. J Autism Dev Disord 2006;36:849-861.

5. Ghaziuddin M, Tsai L, Ghaziuddin N. Comorbidity of autistic disorder in children and adolescents. Eur Child Adolesc Psychiatry 1992;1:209-213.

6.Ghaziuddin M, Weidmer-Mikhail E, Ghaziuddin, N. Comorbidity of Asperger syndrome: a preliminary report. J Intellect Disabil Res 1998;42:279-283.

7. Frazier JA, Doyle R, Chiu S, Coyle JT. Treating a child with Asperger's disorder and comorbid bipolar disorder. Am. J. Psychiatry 2002;159:13-21.

8. Gutkovich ZA, Carlson GA, Carlson HE, Coffey B, Wieland N. Asperger's disorder and co-morbid bipolar disorder: diagnostic and treatment challenges. J Child Adolesc Psychopharmacol 2007; 17:247-255.

9. Kurita H, Osada H, Shimizu K, Tachimori H, Bipolar disorders in mentally retarded persons with pervasive developmental disorders. J Dev Phys Disabil 2004;16:377-389.

10. Wozniak J, Biederman J, Faraone SV, Frazier J, Kim J, Millstein R, Gershon J, Thornell A, Cha K, Snyder JB. Mania in children with pervasive developmental disorder revisited. J Am Acad Child Adolesc Psych 1997;36:1552-1560.

11. Munesue T, Ono Y, Mutoh K, Shimoda K, Nakatani H, Kikuchi, M. High prevalence of bipolar disorder comorbidity in adolescents and young adults with high-functioning autism spectrum disorder: A preliminary study of 44 outpatients. J Affect Disorder 2008;111:170-5.

12.Axelson D, Birmaher B, Strober M, Gill MK, Valeri S, Chiappetta L, Ryan N, Leonard H, Hunt J, Iyengar S, Bridge J, Keller M. Phenomenology of children and adolescents with bipolar spectrum disorders. Arch Gen Psychiatry 2006;63:11391148

13. Kennedy SH, Kutcher SP, Ralevski E, Brown GM. Nocturnal melatonin and 24-hour 6-sulphatoxymelatonin levels in various phases of bipolar affective disorder. Psychiatry Res 1996;63: 219-222.

14. Melke J, Goubran Botros H, Chaste P, Betancur C, Nygren G. Anckarsäter H, Rastam M, Ståhlberg O, Gillberg IC et al. Abnormal melatonin synthesis in autism spectrum disorders. Mol Psychiatry 2008;13:90-98.

15. Harvey AG, Mullin BC, Hinshaw SP. Sleep and circadian rhythms in children and adolescents with bipolar disorder. Dev. Psychopathol 2006;18:1147-1168.

16. Limoges E, Mottron L, Bolduc C, Berthiaume C, Godbout
R. Atypical sleep architecture and the autism phenotype. Brain 2005;128:1049-1061.

17. Lainhart JE, Folstein SEM. Affective disorders in people with autism: a review of published cases. J. Autism Dev Disord 1994;24:587-601

18-Nagaraj R, Singhi P, Malhi P. Risperidone in children with autism: Randomized, placebo-controlled, double-blind study. J Child Neurol 2006;21:450-455.

19-Shea S, Turgay A, Carroll A, Schulz M, Orlik H, Smith L, Dunbar F. Risperidone in the treatment of disruptive behavioral symptoms in children with autistic and other pervasive developmental disorders. Pediatrics 2004;114:634-641.

20-Munesue T, Ono Y, Mutoh K, Shimoda K, Nakatani H, Kikuchi M. High prevalence of bipolar disorder comorbidity in adolescents and young adults with high-functioning autism spectrum disorder: A preliminary study of 44 outpatients, Journal of Affective Disorders 2008;111:170-175. 